\title{
Hubungan Goal Orientation dengan Perilaku Menyontek Siswa Sekolah Menengah Pertama
}

\author{
Allifah Novi Septiani ${ }^{*}$, Akhmad Nayazik ${ }^{2}$, Prihadi Kurniawan ${ }^{3}$ \\ $1,2,3$ Universitas Ivet \\ *allif.septian1@gmail.com
}

Diterima: April 2019. Disetujui: Juni 2019. Dipublikasikan: Juli 2019.

\begin{abstract}
ABSTRAK
Perilaku menyontek dianggap menjadi hal yang biasa dikalangan siswa maupun mahasiswa, sehingga perlu untuk dicarikan solusi dan langkah pemecahan masalah dalam hal ini. Banyak faktor yang menyebabkan masalah ini, diantaranya adalah orientasi akademik siswa. Perilaku menyontek dalam penelitian ini dikategorikan menjadi nilai kepribadian menyontek dan kuantitas praktik menyontek siswa. Penelitian ini bertujuan 1) untuk mengetahui hubungan antara goal orientation dengan nilai kepribadian menyontek siswa Sekolah Menengah Pertama pada pelajaran matematika, 2) untuk mengetahui hubungan antara nilai kepribadian menyontek dengan kuantitas praktik menyontek siswa, 3) untuk mengetahui hubungan antara goal orientation dengan kuantitas praktik menyontek siswa. Jenis penelitian ini adalah penelitian deskriptif kuantitatif. Subyek penelitian adalah siswa kelas VII Madrasah Tsanawiyah Negeri 4 Demak yang diambil 26 siswa dengan random sampling. Metode pengumpulan data yang digunakan adalah angket, soal tes matematika, observasi, dan wawancara. Hasil penelitian menunjukkan bahwa ada hubungan yang signifikan antara goal orientation perilaku menyontek siswa. Hal ini dapat dilihat dari ketiga hasil uji hipotesisnya yaitu ada hubungan negatif dan signifikan antara goal orientation dengan nilai kepribadian menyontek, ada hubungan positif dan signifikan antara nilai kepribadian menyontek dengan kuantitas praktik menyontek siswa, serta ada hubungan negatif dan signifikan antara goal orientation dengan kuantitas praktik menyontek siswa.
\end{abstract}

Kata kunci: goal orientation, kepribadian menyontek, kuantitas praktik menyontek.

\begin{abstract}
Cheating is considered to be common among students. It is necessary to find solutions to solve this problem. There are so many factors that cause this problem, one is the student's academic orientation. Cheating in this research was categorized as students' cheating personality values and the quantity of cheating habit. This study aims: 1) to determine the relationship between students' goal orientation and cheating personality values on mathematics class in junior high school, 2) to find out the relationship between students' cheating personality values and the quantity of cheating habit on mathematics class in junior high school, 3) to find out the relationship between students' goal orientation and the quantity of cheating habit on mathematics class in junior high school. This is a quantitative descriptive research. The subjects were VII grade students of Madrasah Tsanawiyah Negeri 4 Demak. There were 26 students taken by random sampling. Questionnaires, math test questions, observation, and interviews were used to collect the data. There is a significant relationship between the students' goal orientation and their cheating behavior. There is a negative significant relationship between goal orientation and cheating personality values. There is a positive significant relationship between cheating personality values and the quantity of cheating habit. There is a negative significant relationship between the goal orientation and the quantity of cheating habit. Keywords: goal orientation, personality cheating, quantity of cheating practices.
\end{abstract}

How to Cite: Septiani, A., Nayazik, A., \& Kurniawan, P. (2019). Hubungan Goal Orientation dengan Perilaku Menyontek Siswa Sekolah Menengah Pertama pada Pelajaran Matematika. Journal Of Medives : Journal Of Mathematics Education IKIP Veteran Semarang, 3(2), 307-314. 


\section{PENDAHULUAN}

Menurut (Masrun, 2004), aktivitas ketidakjujuran dalam pendidikan sebenarnya merupakan masalah serius. Ketidakjujuran dalam pendidikan bertentangan dengan tujuan pendidikan nasional. Menurut (Djauhari \& Wardani, 2018), perilaku menyontek (cheating) merupakan salah satu fenomena pendidikan yang sering dan bahkan selalu muncul menyertai aktivitas proses pembelajaran.

Menurut (Perianto, 2015); (Pujiatni \& Lestari, 2010); (Djauhari \& Wardani, 2018); (Masrun, 2004), (Murdiansyah, Sudarma, \& Nurkholis -, 2017), menyontek merupakan perbuatan curang, tidak jujur dalam mendapatkan jawaban yang baik dalam ujian, tes, dan sudah tentu berbagai macam cara dilakukan untuk mencapai tujuan itu. Sejalan dengan (Miranda, 2017), kurangnya perhatian mengenai perilaku menyontek disebabkan oleh kurangnya kesadaran bahwa masalah menyontek bukan merupakan sesuatu yang sifatnya sepele. Perilaku menyontek ini dilakukan secara terorganisir mulai dari pembentukan tim penyebaran kunci jawaban sehingga seluruh siswa-siswi dikelas dapat menerima contekan dan mendapatkan nilai terbaik.

Menyontek dipandang sebagai salah satu bentuk perilaku ketidakjujuran akademik (academic dishonesty) yang dapat ditemukan di sekolah-sekolah, baik tingkat SD, SMP, SMA maupun perguruan tinggi (Pujiatni \& Lestari, 2010); (Sagoro, 2013); (Ismatullah \& Eriswanto, 2016).

Goal orientation mencerminkan jenis standar dengan mana individu- individu menilai kinerja diri sendiri, keberhasilan atau kegagalan dalam mencapai tujuan (Schunk, Meece, \& Pintrich, 2012). Goal orientation dibagi menjadi 2 yaitu mastery goal orientation (orientasi penguasaan terhadap materi) dan performance goal orientation (orientasi nilai dari pembelajaran yang dilaksanakan).

Sejauh yang peneliti ketahui bahwa penelitian goal orientation dan menyontek hanya berfokus pada kepribadian menyontek siswa menggunakan instrument angket/kuesioner sebagai alat pengambil data. Sedangkan penelitian yang berfokus pada kuantitas praktik menyontek siswa belum pernah dilakukan. Kuantitas praktik menyontek siswa merupakan data faktual mengenai perilaku menyontek siswa yang terjadi di lapangan. Berdasarkan hasil pemaparan di atas, maka ada indikasi bahwa orientasi akademik (goal orientation) dapat menjelaskan terjadinya perilaku menyontek pada pelajaran matematika.

\section{METODE PENELITIAN}

Jenis penelitian yang digunakan adalah penelitian kuantitatif deskriptif yang mencari hubungan antara variabelvariabel yang diteliti. Subyek penelitian ini adalah siswa-siswi kelas VIII MTs Negeri 4 Demak yang berjumlah 26 siswa. Adapun teknik pengambilan sampel dalam penelitian ini adalah dengan menggunakan random sampling sederhana (Simple Random Sampling).

Data yang diperlukan dalam penelitian ini, meliputi data goal orientaion, kepribadian menyontek, dan kuantitas praktik menyontek siswa pada pelajaran matematika. Pengumpulan 
data dilakukan dengan menggunakan kuesioner, soal tes matematika, dan wawancara.

Analisis data yang digunakan adalah analisis Korelasi Pearson yang digunakan untuk menguji hipotesis asosiatif (uji hubungan) dua variabel, peneliti menambahkan analisis regresi sederhana.

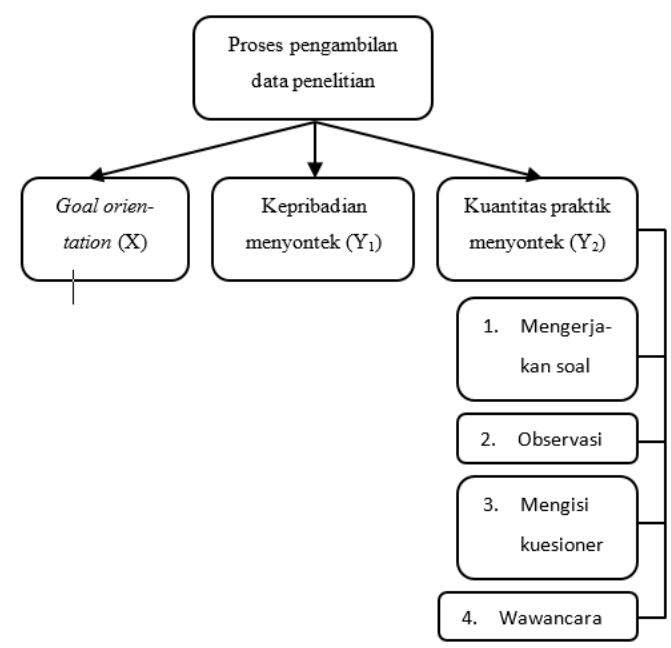

Gambar 1. Proses Pengambilan Data

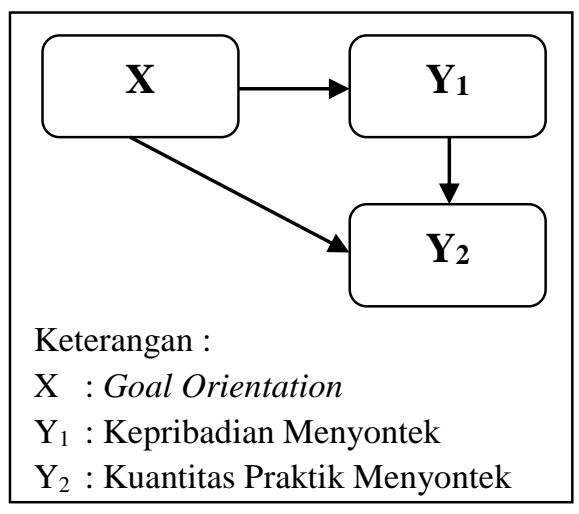

Gambar 2. Kerangka Pikir

\section{HASIL DAN PEMBAHASAN \\ Uji Normalitas.}

Hasil uji normalitas dari variabel goal orientation diperoleh nilai signifikansi Saphiro-Wilk $\mathrm{p}=0,824(\mathrm{p}>0,05)$ hasil ini menunjukkan bahwa hasil sebaran data variabel goal orientation memenuhi distribusi normal. Selanjut- nya hasil uji normalitas dari variabel kepribadian menyontek diperoleh nilai signifikansi Saphiro-Wilk p = 0,312 (p > 0,05 ) hasil ini menunjukkan bahwa hasil sebaran data variabel goal orientation memenuhi distribusi normal, dan hasil uji normalitas dari variabel kuantitas praktik menyontek diperoleh nilai signifikansi Saphiro-Wilk p = 0,369 (p > $0,05)$ hasil ini menunjukkan bahwa hasil sebaran data variabel goal orientation memenuhi distribusi normal.

Tabel 1. Output Uji Normalitas

\begin{tabular}{|c|c|c|c|c|c|c|}
\hline \multicolumn{7}{|c|}{ Tests of Normality } \\
\hline & \multicolumn{3}{|c|}{ Kolmogorov-Smirnova } & \multicolumn{3}{|c|}{ Shapiro-Wilk } \\
\hline & Statistic & df & Sig. & Statistic & df & Sig. \\
\hline goal_orientation & .112 & 26 & $.200^{\circ}-3=0$ & .978 & 26 & .824 \\
\hline kepribadian menyontek & .128 & 26 & $.200^{\circ}-3$ & .956 & 26 & .312 \\
\hline kuantitas_praktik_ & .134 & 26 & .200 & .959 & 26 & .369 \\
\hline & & & & & & \\
\hline
\end{tabular}

\section{Uji Linearitas}

Berdasarkan Tabel 2 diperoleh nilai $F_{\text {hitung }}=0,828\left(F_{\text {hitung }}<F_{\text {tabel }}=2,76\right)$; signifikansi $(\mathrm{p})=0,631 ;(\mathrm{p}>0,05)$ hasil ini menunjukkan bahwa variabel goal orientation $(\mathrm{X})$ dengan variabel kepribadian menyontek $\left(\mathrm{Y}_{1}\right)$ memiliki korelasi yang searah (linear). Selanjutnya hasil uji linearitas hubungan antara variabel kepribadian menyontek ( $\left.\mathrm{Y}_{1}\right)$ dengan variabel kuantitas praktik menyontek $\left(\mathrm{Y}_{2}\right)$ diperoleh nilai $F_{\text {hitung }}=2,653\left(F_{\text {hitung }}\right.$ $\left.<\mathrm{F}_{\text {tabel }}=2,76\right)$; signifikansi $(\mathrm{p})=0,057$; ( $\mathrm{p}>0,05)$ hasil ini menunjukkan bahwa variabel kepribadian menyontek ( $\left.\mathrm{Y}_{1}\right)$ dengan variabel kuantitas praktik menyontek $\left(\mathrm{Y}_{2}\right)$ memiliki korelasi yang searah (linear). Kemudian hasil uji linearitas hubungan antara variabel goal orientation (X) dengan variabel kuantitas praktik menyontek $\left(\mathrm{Y}_{2}\right)$ 
diperoleh nilai $F_{\text {hitung }}=0,365\left(F_{\text {hitung }}<\right.$ $\left.\mathrm{F}_{\text {tabel }}=2,69\right)$; signifikansi $(\mathrm{p})=0,956 ;(\mathrm{p}$ $>0,05)$ hasil ini menunjukkan bahwa goal orientation $(\mathrm{X})$ dengan variabel kuantitas praktik menyontek $\left(\mathrm{Y}_{2}\right)$ memiliki korelasi yang searah (linear).

Tabel 2. Hasil Uji Linearitas

\begin{tabular}{|l|l|l|l|l|}
\hline \multicolumn{1}{|c|}{ Variabel } & \multicolumn{1}{|c|}{ Ftabel } & Fhitung & \multicolumn{1}{|c|}{ Sig. } & Hasil \\
\hline $\mathrm{X}$ dengan Y1 & 2,76 & 0,828 & 0,631 & Linear \\
\hline Y1 dengan Y2 & 2,76 & 2,653 & 0.057 & Linear \\
\hline X dengan Y2 & 2,69 & 0,365 & 0,956 & Linear \\
\hline
\end{tabular}

\section{Uji Korelasi Product Moment}

Berdasarkan Tabel 3, diperoleh nilai $r_{x y 1}=(-0,733)$ dengan nilai signifikansi $p=0,000(p<0,05)$ hal ini menunjukkan bahwa terjadi hubungan yang kuat antara goal orientation dan kepribadian menyontek siswa, sedangkan nilai $r_{y 1 y 2}=(0,649)$ dengan signifikansi $\mathrm{p}=0,000(\mathrm{p}<0,05)$ hal ini menunjukkan bahwa terjadi hubungan yang kuat antara kepribadian menyontek dengan kuantitas praktik menyontek siswa. Berdasarkan Tabel 3, nilai $\mathrm{r}_{\mathrm{xy} 2}=(-0,811)$ dengan signifikansi $p=0,000(p<0,05)$ hal ini menunjukkan bahwa terjadi hubungan yang kuat antara goal orientation dan kuantitas praktik menyontek siswa.

Tabel 3. Output Uji Korelasi

\begin{tabular}{|c|c|c|c|c|}
\hline & & $\mid \begin{array}{c}\text { Goal__ } \\
\text { Orientation }\end{array}$ & $\begin{array}{r}\text { Kepribadian } \\
\text {-Menyontek }\end{array}$ & $\begin{array}{c}\text { Kuantitas_ } \\
\text { Praktik__ } \\
\text { Menyontek }\end{array}$ \\
\hline $\begin{array}{c}\text { Goal__ } \\
\text { Orientation }\end{array}$ & $\begin{array}{l}\text { Pearson Correlation } \\
\text { Sig. (2-tailed) } \\
\mathrm{N}\end{array}$ & 26 & $\begin{array}{r}-.733^{*+} \\
.000 \\
26 \\
\end{array}$ & $\begin{array}{r}-.811^{* *} \\
.000 \\
26 \\
\end{array}$ \\
\hline $\begin{array}{l}\text { Kepribadian_ } \\
\text { Menyontek }\end{array}$ & $\begin{array}{l}\text { Pearson Correlation } \\
\text { Sig. (2-tailed) } \\
\mathrm{N} \\
\end{array}$ & $\begin{array}{r}-.733^{* *} \\
.000 \\
26 \\
\end{array}$ & 26 & $\begin{array}{r}.649^{* *} \\
.000 \\
26 \\
\end{array}$ \\
\hline $\begin{array}{l}\text { Kuantitas_ } \\
\text { Praktik_ } \\
\text { Menyontek }\end{array}$ & $\begin{array}{l}\text { Pearson Correlation } \\
\text { Sig. (2-tailed) } \\
\mathrm{N}\end{array}$ & $\begin{array}{r}-.811^{* *} \\
.000 \\
26\end{array}$ & $\begin{array}{r}.649^{* 4} \\
.000 \\
26\end{array}$ & 26 \\
\hline
\end{tabular}

\section{Uji Regresi Linear}

Dari Tabel 4, diperoleh nilai signifikansi goal orientation (X) terhadap nilai kepribadian menyontek (Y1) adalah 0,000 < 0,05 maka dapat disimpulkan bahwa secara langsung terdapat pengaruh yang signifikan $\mathrm{X}$ terhadap Y1.

Tabel 4. Output Coefficients Uji Regresi X terhadap Y1

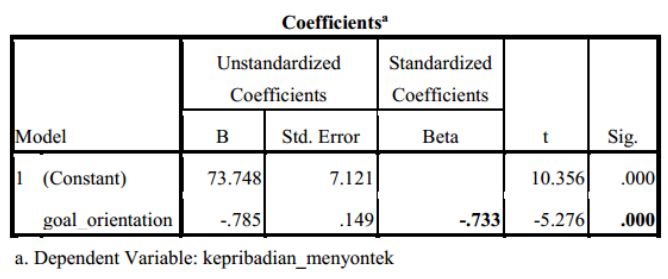

Tabel 5. Output Model Summary Uji Regresi X terhadap Y1 Model Summary

\begin{tabular}{|l|r|r|r|r|}
\hline & \multicolumn{1}{|c|}{ Model Summary } \\
\hline Model & $\mathrm{R}$ & \multicolumn{1}{c|}{ R Square } & $\begin{array}{c}\text { Adjusted R } \\
\text { Square }\end{array}$ & $\begin{array}{c}\text { Std. Error of the } \\
\text { Estimate }\end{array}$ \\
\hline 1 & $.733^{\mathrm{a}}$ &. $\mathbf{5 3 7}$ & .518 & 3.425 \\
\hline
\end{tabular}

a. Predictors: (Constant), goal orientation

Tabel 5 menunjukkan besar pengaruh variabel $\mathrm{X}$ terhadap variabel $\mathrm{Y} 1$ dapat dilihat dari $\mathrm{R}$ Square yang menunjukkan nilai 0,537 yang artinya goal orientation mempengaruhi kepribadian menyontek siswa sebesar 53,7\% sedangkan $46,3 \%$ sisanya dipengaruhi oleh variabel lain di luar penelitian.

Tabel 6. Output Coefficients Uji Regresi Y1 terhadap Y1

\begin{tabular}{|c|c|c|c|c|c|}
\hline \multirow[b]{2}{*}{ Model } & \multicolumn{2}{|c|}{$\begin{array}{c}\text { Unstandardized } \\
\text { Coefficients }\end{array}$} & \multirow{2}{*}{ 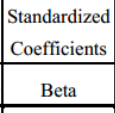 } & \multirow[b]{2}{*}{$\mathrm{t}$} & \multirow[b]{2}{*}{ Sig. } \\
\hline & B & Std. Error & & & \\
\hline 1 (Constant) & -6.339 & 3.295 & & -1.923 & .066 \\
\hline $\begin{array}{l}\text { kepribadian_ } \\
\text { menyontek }\end{array}$ & .375 & .090 & .649 & 4.177 & .000 \\
\hline
\end{tabular}

Dari Tabel 6 diperoleh nilai signifikansi kepribadian menyontek 
(Y1) terhadap kuantitas praktik menyontek (Y2) adalah $0,000<0,05$ maka dapat disimpulkan bahwa secara langsung terdapat pengaruh yang signifikan Y1 terhadap Y2.

Tabel 7. Output Model Summary Uji Regresi Y1

terhadap Y2
\begin{tabular}{|l|c|c|c|c|}
\hline Model & \multicolumn{1}{|c|}{ R } & R Square & $\begin{array}{c}\text { Adjusted R } \\
\text { Square }\end{array}$ & $\begin{array}{c}\text { Std. Error of the } \\
\text { Estimate }\end{array}$ \\
\hline 1 & .649 & .421 & .397 & 2.216 \\
\hline
\end{tabular}

a. Predictors: (Constant), kepribadian menyontek

Tabel 7 menunjukkan besar pengaruh variabel Y1 terhadap variabel Y2 dapat dilihat dari $\mathrm{R}$ Square yang menunjukkan nilai 0,421 yang artinya kuantitas praktik menyontek dipengaruhi oleh kepribadian menyontek siswa sebesar $42,1 \%$ sedangkan $57,9 \%$ sisanya dipengaruhi oleh variabel lain diluar penelitian.

Tabel 8. Output Coefficients Uji Regresi X terhadap Y2

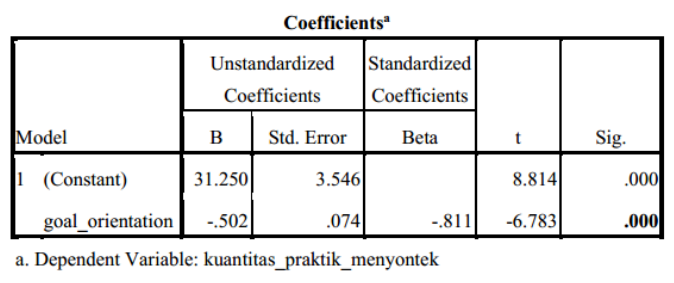

Dari Tabel 8 diperoleh nilai signifikansi goal orientation (X) terhadap kuantitas praktik menyontek (Y2) adalah 0,000 < 0,05 maka dapat disimpulkan bahwa secara langsung terdapat pengaruh yang signifikan $\mathrm{X}$ terhadap Y2.

Tabel 9 menunjukkan besar pengaruh variabel $\mathrm{X}$ terhadap variabel Y2 dapat dilihat dari R Square yang menunjukkan nilai 0,657 yang artinya kuantitas praktik menyontek dipengaruhi oleh goal orientation sebesar $65,7 \%$. sedangkan $34,3 \%$ sisanya dipengaruhi oleh variabel lain di luar penelitian. Dari berbagai hasil pengujian diatas maka dapat disimpulkan bahwa antar variabel penelitian selain memiliki hubungan yang signifikan juga memiliki pengaruh yang signifikan.

Tabel 9. Output Model Summary Uji Regresi X terhadap Y2

\begin{tabular}{|l|r|r|c|c|}
\hline Model & \multicolumn{1}{|c|}{ Model Summary } \\
\hline 1 & $.811^{\mathrm{a}}$ & $\mathrm{R}$ Square & $\begin{array}{c}\text { Adjusted R } \\
\text { Square }\end{array}$ & $\begin{array}{c}\text { Std. Error of the } \\
\text { Estimate }\end{array}$ \\
\hline
\end{tabular}
a. Predictors: (Constant), goal_orientation
.657

\section{PEMBAHASAN}

Hasil penelitian ini menunjukkan bahwa goal orientation memiliki hubungan dengan nilai kepribadian menyontek siswa sekolah menengah pertama pada pelajaran matematika. Hasil penelitian ini juga menunjukkan bahwa 46,154\% atau sejumlah 12 siswa cenderung mastery goal orientation, $42,308 \%$ atau sejumlah 11 siswa cenderung performance goal orientation, dan $11,538 \%$ atau 3 siswa seimbang antara mastery dan performance goal orientationnya.

Hasil output yang ditunjukkan Tabel 5 nilai korelasi antara goal orientation dengan nilai kepribadian menyontek sebesar $-0,733$. Hal ini dapat diartikan bahwa goal orientation memiliki hubungan yang negatif dengan nilai kepribadian menyontek. Sejalan dengan penelitian (Alawiyah, 2011); (Susanto, 2018); (Muktamam, 2010), (Aziroh, 2018); (Samiroh \& Muslimin, 2015), bahwa performance goal orientation memiliki hubungan yang negatif dengan menyontek. 
Temuan penelitian ini berbeda dengan (Hendra, 2012) bahwa orientasi akademik atau goal orientation memiliki hubungan yang sangat signifikan dengan perilaku menyontek siswa. Lain hanya (Darojah, 2017) bahwa terdapat hubungan yang positif dan signifikan antara orientasi tujuan dengan perilaku menyontek siswa.

Hasil penelitian yang telah dilaksanakan peneliti menunjukkan bahwa nilai kepribadian menyontek memiliki hubungan dengan kuantitas praktik menyontek siswa sekolah menengah pertama pada pelajaran matematika. Hasil output yang ditunjukkan Tabel 7 nilai korelasi antara nilai kepribadian menyontek dengan kuantitas praktik menyontek sebesar 0,649 . Hal ini dapat diartikan bahwa nilai kepribadian menyontek memiliki hubungan yang positif dengan kuantitas praktik menyontek. Temuan yang sama oleh (Susanto, 2018) bahwa terdapat hubungan positif antara tekanan akademik dengan kecurangan akademik.

Pengujian lebih lanjut pada Tabel 7 menunjukkan bahwa nilai $\mathrm{R}^{2}$ atau nilai $\mathrm{R}$ Square sebesar 0,421. Nilai ini menunjukkan bahwa pengaruh nilai kepribadian menyontek terhadap kuantitas praktik menyontek siswa adalah sebesar $42,1 \%$, sedangkan $57,9 \%$ sisanya dipengaruhi oleh variabel lain di luar penelitian ini.

Hasil penelitian yang telah dilaksanakan peneliti menunjukkan bahwa analisis korelasi yang digunakan untuk goal orientation memiliki hubungan dengan kuantitas praktik menyontek siswa sekolah menengah pertama pada pelajaran matematika.
Hasil output yang ditunjukkan Tabel 9 nilai korelasi antara goal orientation dengan kuantitas praktik menyontek sebesar $-0,811$. Hal ini dapat diartikan bahwa goal orientation memiliki hubungan yang negatif dengan kuantitas praktik menyontek. Pengujian lebih lanjut pada Tabel 9 menunjukkan bahwa nilai $\mathrm{R}^{2}$ atau nilai $\mathrm{R}$ Square sebesar 0,657. Nilai ini menunjukkan bahwa pengaruh goal orientation terhadap kuantitas praktik menyontek siswa adalah sebesar $65,7 \%$, sedangkan $54,3 \%$ sisanya dipengaruhi oleh variabel lain di luar penelitian ini. Sejalan dengan penelitian (Alawiyah, 2011); (Susanto, 2018), bahwa goal orientation memiliki hubungan yang negatif terhadap praktik menyontek.

\section{SIMPULAN DAN SARAN \\ Simpulan}

Berdasarkan hasil penelitian, maka simpulan sebagai berikut. (1) Terdapat hubungan yang negatif dan signifikan antara goal orientation dengan nilai kepribadian menyontek siswa Sekolah Menengah Pertama dengan nilai korelasi sebesar $-0,733$ dan sumbangan efektif sebesar 53,7\%. (2) Terdapat hubungan yang positif dan signifikan antara nilai kepribadian menyontek dengan kuantitas praktik menyontek siswa Sekolah Menengah Pertama dengan nilai korelasi sebesar 0,649 dan sumbangan efektif sebesar $42,1 \%$. (3) Terdapat hubungan yang negatif dan signifikan antara goal orientation dengan kuantitas praktik menyontek siswa Sekolah Menengah Pertama dengan nilai korelasi -0,811 dan sumbangan efektif sebesar $65,7 \%$. 


\section{Saran}

Penelitian selanjutnya diharapkan untuk memperluas penggunaan sampel, yaitu menggunakan sampel kelas satu dan tiga SMP karena sampel tingkat SMP masih jarang diteliti. Selain itu, agar tercapai generalisasi, penggunaan populasi tidak hanya menggunakan satu tempat saja dan tehnik sampling yang digunakan sebaiknya secara probability sampling. Alat ukur dalam penelitian ini, peneliti mengadopsi alat ukur yang telah digunakan sebelumnya maka dari itu untuk penelitian selanjutnya diharapkan untuk dapat mengembangkan alat ukur sendiri agar lebih tepat sasaran ketika digunakan dalam penelitian. Oleh karena itu penelitian selanjutnya sangat diharapkan untuk melibatkan variabel-variabel lain seperti peran nilai kejujuran, sistem pengawasan guru, konformitas, self efficacy, jenis kelamin, umur, pola asuh dan lain-lain yang tentunya memiliki hubungan dengan perilaku menyontek walaupun nilainya tidak begitu signifikan.

\section{DAFTAR PUSTAKA}

Alawiyah, H. (2011). Pengaruh selfefficacy, konformitas dan goal orientation terhadap perilaku menyontek (cheating) siswa MTs alhidayah Bekasi. Retrieved from http://repository.uinjkt.ac.id/dspace/h andle/123456789/1758

Aziroh, L. F. (2018). Pengaruh regulasi diri dan motivasi berprestasi terhadap perilaku menyontek siswa siswi MTs Miftahul Huda Bulungan Pakis Aji Jepara (Undergraduate, UIN Walisongo). Retrieved from http://eprints.walisongo.ac.id/8231/
Darojah, F. (2017). Hubungan Efikasi Diri dan Orientasi Tujuan dengan Perilaku Menyontek Siswa Kelas XI Akuntasi di SMK Tirta Sari Surya Tahun Ajaran 2016-2017 (Skripsi, Universitas Negeri Jakarta). Retrieved from http://repository.fe.unj.ac.id/1332/

Djauhari, D., \& Wardani, S. I. (2018). Pengaruh Self-Efficacy dan Harapan Orang Tua terhadap Prestasi Terhadap Perilaku Menyontek pada Siswa. PSIKOSAINS (Jurnal Penelitian Dan Pemikiran Psikologi), 11(1), 17-29. https://doi.org/10.30587/psikosains.v 11 i1.633

Hendra, H. (2012). Hubungan Antara Efikasi Diri Dan Orientasi Akademik Dengan Perilaku Menyontek Siswa Pada Mata Pelajaran Matematika (S2, Universitas Muhammadiyah Surakarta).

http://eprints.ums.ac.id/22158/10/DA FTAR_PUSTAKA.pdf

Ismatullah, I., \& Eriswanto, E. (2016). Analisa Pengaruh Teori Gone Fraud terhadap Academic Fraud di Universitas Muhammadiyah Sukabumi. Riset Akuntansi Dan Keuangan Indonesia, 1(2), 134-142142.

https://doi.org/10.23917/reaksi.v1i2. 2731

Masrun, Y. I. and. (2004). Hubungan Antara Orientasi Penguasaan dan Orientasi Performasi Dengan Intensi Menyontek (The Correlation between Mastery Oriented and Performance Oriented, and Intention of Cheating). Sosiosains, 17(2004). Retrieved from http://i-

lib.ugm.ac.id/jurnal/detail.php?dataId $=7113$ 
Miranda, L., P. (2017). Pengaruh Konformitas Teman Sebaya dan Minat Belajar terhadap Perilaku Menyontek pada Siswa Kelas X SMA Negeri 3 Bontang. Ejournal Psikologi, 5(1), 39-51.

Muktamam, M. (2010). Hubungan antara Konsep Diri dengan Perilaku Menyontek (S1, Universitas Muhammadiyah Surakarta). Retrieved from http://eprints.ums.ac.id/9273/

Murdiansyah, I., Sudarma, M., \& Nurkholis -. (2017). Pengaruh Dimensi Fraud Diamond terhadap Perilaku Kecurangan Akademik (Studi Empiris pada Mahasiswa Magister Akuntansi Universitas Brawijaya). Jurnal Akuntansi Aktual, 4(2), 121-133.

Perianto, E. (2015). Persepsi Mahasiswa Angkatan 2013/2014 Program Studi Bimbingan dan Konseling terhadap Perilaku Mencontek FKIP Universitas PGRI Yogyakarta. Jurnal Konseling Gusjigang, 1(2). https://doi.org/10.24176/jkg.v1i2.404

Pujiatni, K., \& Lestari, L. (2010). Studi Kualitatif Pengalaman Menyontek Pada Mahasiswa. Retrieved from http://publikasiilmiah.ums.ac.id/hand le/11617/658
Sagoro, E. M. (2013). Pensinergian Mahasiswa, Dosen, dan Lembaga dalam Pencegahan Kecurangan Akademik Mahasiswa Akuntansi. Jurnal Pendidikan Akuntansi Indonesia, 11(2). https://doi.org/10.21831/jpai.v11i2.1 691

Samiroh, S., \& Muslimin, Z. I. (2015). Hubungan antara Konsep Diri Akademik dan Perilaku Menyontek pada Siswa-Siswi Mas Simbangkulon Buaran Pekalongan. Psikis: Jurnal Psikologi Islami, 1(2), 67-77.

Schunk, Meece, \& Pintrich. (2012). Motivation in education: Theory, research, and applications. Pearson Higher Ed.

Susanto, A. H. (2018). Hubungan kepribadian ihsan dan tekanan akademik dengan perilaku kecurangan akademik pada mahasiswa di Universitas $X$ di Surabaya (Undergraduate, UIN Sunan Ampel Surabaya). Retrieved from http://digilib.uinsby.ac.id/26727/ 